\title{
The Editors' Medal 2011
}

\author{
Dierk Vorwerk
}

(C) Springer Science+Business Media, LLC and the Cardiovascular and Interventional Radiological Society of Europe (CIRSE) 2011

Every year since 2003, the Editorial Board has chosen publications from the previous volume for nomination of the Editors' Medal. The winners are selected by a poll among all members of the Editorial Board and include original and experimental submissions only.

In response to the continued increase in qualifying articles, reader interest, author submissions, and the numerous nominations by the editorial board members, the editors decided this year to honor four author groups for their outstanding contributions to CVIR. This year it is our pleasure to give the Editors' Medal 2011 to the author groups listed below. This award comes with a considerable donation from our publisher, Springer Science + Business Media, LLC. Congratulations to all the winners, and thank you for making CVIR your preferred journal for submissions.

\section{Bibliography}

1. Bruners P, Braunschweig T, Hodenius M, Pietsch H, Penzkofer T, Baumann M, Günther RW, Schmitz-Rode T, Mahnken AH (2010)
Thermoablation of malignant kidney tumors using magnetic nanoparticles: an in vivo feasibility study in a rabbit model. Cardiovasc Intervent Radiol 33(1):127-134. Epub 2009 May 9

2. Lammer J, Malagari K, Vogl T, Pilleul F, Denys A, Watkinson A, Pitton M, Sergent G, Pfammatter T, Terraz S, Benhamou Y, Avajon Y, Gruenberger T, Pomoni M, Langenberger H, Schuchmann M, Dumortier J, Mueller C, Chevallier P, Lencioni R; PRECISION V Investigators (2010) Prospective randomized study of doxorubicin-eluting-bead embolization in the treatment of hepatocellular carcinoma: results of the PRECISION V study. Cardiovasc Intervent Radiol 33(1):41-52. Epub 2009 Nov 12

3. Peregrin JH, Koznar B, Kovác J, Lastovicková J, Novotný J, Vedlich D, Skibová J (2010) PTA of infrapopliteal arteries: longterm clinical follow-up and analysis of factors influencing clinical outcome. Cardiovasc Intervent Radiol 33(4):720-725. Epub 2010 May 11

4. Spiliopoulos S, Katsanos K, Karnabatidis D, Diamantopoulos A, Kagadis GC, Christeas N, Siablis D (2010) Cryoplasty versus conventional balloon angioplasty of the femoropopliteal artery in diabetic patients: long-term results from a prospective randomized single-center controlled trial. Cardiovasc Intervent Radiol 33(5):929-938. Epub 2010 Jun 24

D. Vorwerk $(\bowtie)$

Department of Radiology, Klinikum Ingolstadt,

Krumenauerstrasse 25, Ingolstadt 85049, Germany

e-mail: dierk.vorwerk@klinikum-ingolstadt.de 